\title{
PKM KELOMPOK PEDAGANG PASAR DALAM PENERAPAN PROTOKOL KESEHATAN
}

\author{
Putu Indah Budi Apsari, Ni Wayan Widhidewi \\ Fakultas Kedokteran dan Ilmu Kesehatan, Universitas Warmadewa
}

\begin{abstract}
Abstrak
Sejak terjadinya pandemi Corona Virus Disease 19 di Indonesia, terjadi perubahan peraturan pembukaan tempat umum utamanya pasar. Aturan ini diterapkan untuk megurangi kontak pembeli dengan pedagang untuk memutus rantai penularan Covid-19 di pasar akibatnya adalah penurunan pendapatan pedagang. Tujuan pengabdian kepada masyarakat ini adalah menyasar Pasar Yadnya sebagai sasaran pengabdian PKM penerapan protokol kesehatan. Metode yang digunakan adalah survey, observasi, melakukan pemetaan, menentukan dan menetapkan kelompok pedagang pasar Yadnya yang menjadi peserta. Untuk menambah kelengkapan data, kami melakukan wawancara dengan Kepala pasar yang mengetahui bagaimana aktivitas pedagang dan pembeli di pasar tersebut. Pelaksanaan kegiatan meliputi pembuatan sekat transparan yang akan membatasi transmisi droplet pembeli dan penjual, pengaturan jarak dengan memasang tanda silang pada tempat-tempat tertentu, penyediaan wastafel dan air untuk cuci tangan, penerapan aturan skrining dengan termogun di depan pasar, pembagian masker standar yang disarankan oleh WHO, penyuluhan dan pelatihan cara cuci tangan 6 langkah dengan teknik tanpa sentuh. Kesimpulan terdapat peningkatan pengetahuan dan keterampilan peserta dalam melaksanakan protokol kesehatan.
\end{abstract}

Keyword: pedagang, pasar, protokol, kesehatan

\section{PENDAHULUAN}

Di Kota Denpasar terdapat 51 pasar, sebanyak 35 di antaranya dikelola Badan Pemberdayaan Masyarakat (BPM) Kota Denpasar dan 16 lainnya dikelola PD Pasar Kota Denpasar. ${ }^{1}$ Pasar desa atau pasar tradisional tidak hanya tempat jual beli, tetapi juga tempat berinteraksi bagi masyarakat. Tawar-menawar dan tegur sapa ini menjadi ciri pasar tradisional yang tidak ditemukan di pasar modern. Pemberdayaaan pasar tradisional sebagai upaya memberdayakan perekonomian masyarakat akar rumput. Pasar tradisional merupakan pasar yang menjadi penyumbang pertumbuhan ekonomi di Indonesia. ${ }^{2}$

Penambahan jumlah kasus Covid dibarengi munculnya klaster-klaster baru. Salah satunya di Kota Denpasar, dimana muncul dua klaster baru terkait penyebaran wabah virus Covid-19. ${ }^{3}$ Klaster baru banyak muncul di Kota Denpasar, sebagian besar merupakan klaster keluarga serta ada klaster pasar tradisional. Saat ini 
sebagian besar kasus covid-19 disebabkan transmisi lokal. ${ }^{4}$ Sejumlah pasar tradisional di Indonesia menjadi klaster baru penyebaran virus corona, setelah ratusan pedagang di sejumlah daerah, seperti Padang, Palangkaraya dan Jakarta, terinfeksi virus corona. Ikatan Pedagang Pasar Tradisional Indonesia (IKAPPI) mencatat sebanyak 573 pedagang terinfeksi Covid-19. Setidaknya 32 orang di antaranya meninggal dunia. ${ }^{5}$ Di Indonesia, secara keseluruhan terdapat sekitar 14.000 pasar tradisional. Pasar tradisional berpotensi besar menjadi kluster penyebaran virus corona karena contact rate di lokasi itu sangat tinggi. ${ }^{6}$ Sebelumnya, beberapa daerah yang juga melakukan tes masif virus Corona di pasar tradisional menemukan adanya pedagang yang terpapar COVID-19. Pasar tradisional memang menjadi tempat yang cukup rawan dalam kaitannya dengan potensi penyebaran virus Corona. $^{7}$

Berbeda dengan pusat perbelanjaan modern, arus keluar masuk di pasar tradisional tidak bisa dikontrol dan tidak semua pasar telah menerapkan protokol kesehatan bagi pengunjung seperti pengecekan suhu tubuh.
Pasar tradisional situasi dan kondisinya tidak memungkinkan walaupun sebenarnya bisa untuk melaksanakan protokol kesehatan, lebih susah dibandingkan dengan mall. ${ }^{7}$

Melihat permasalahan seperti diuraikan di atas menarik bagi kami untuk turun ke lapangan melakukan pengabdian masyarakat guna melihat lebih dekat berbagai permasalahan yang dihadapi kelompok pedagang pasar tradisional. Untuk membatasi ruang pengabdian, maka mitra yang dipilih adalah Bapak I Ketut Sudana sebagai kepala pasar Yadnya jalan Surabi Denpasar.

Kelompok mitra dalam hal ini pedagang pasar tidak berdaya dengan situasi ini. Mereka menjadi apatis dan tidak peduli, walaupun sebenarnya mereka memiliki keinginan untuk membantu pemerintah dalam memutus mata rantai penularan Covid-19, meningkatkan omset penjualan sebagai sumber potensial kesejahteraan keluarga. Fenomena yang muncul cenderung disebabkan karena 1) kurangnya sarana dan pembinaan; 2) kurangnya pengetahuan akan penerapan protokol kesehatan.
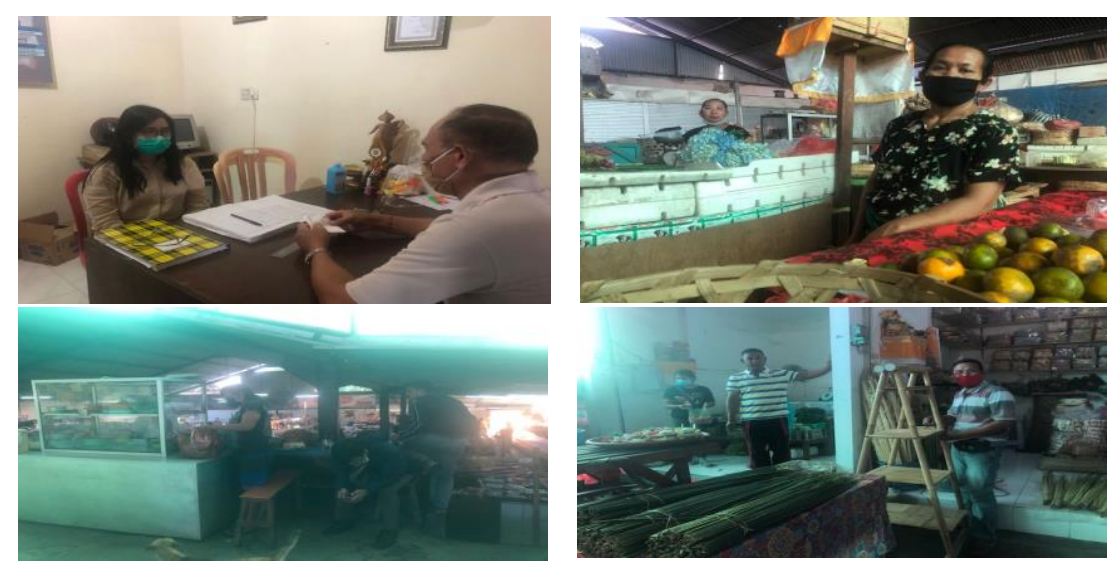

Gambar 1. Analisis situasi pasar Yadnya, Kesiman 
https://ejournal.warmadewa.ac.id/index.php/wicaksana

Identifikasi permasalahan dapat dirinci sebagai berikut:

Masalah Kesehatan. Kelompok mitra mengalami kesulitan dalam masalah kesehatan dimana virus Covid-19 ini penyebarannya sangat cepat dan kita tidak pernah tahu di tengah masyrakat baik pedagang maupun pembeli apakah ada yang terjangkit virus Covid-19 terutama yang tanpa gejala. Kelompok mitra juga kurang mengetahui bagaimana cara penularan, karakteristik virus dan berbahayanya virus ini terutama pada kelompok orang yang rentan seperti anak, anak, ibu hamil, lansia dan orang dengan penyekit penyerta. Kelompok mitra kurang kesadaran dalam penerapan protocol kesehatan dibuktikan dengan masih adanya pedagang yang tidak mengenakan masker dengan benar, tidak menjaga jarak antara pembeli dan penjual. Perilaku hidup bersih dan sehat juga kurang diterapkan dalam hal ini mencuci tangan sebelum masuk pasar, setelah memegang kotoran maupun kebersihan sekitar seperti sampah yang banyak menumpuk di bagian pojok yang mengundang lalat dan binatang lainnya dapat merupakan sumber penularan thypus dan diare.

Berdasarkan uraian analisis situasi, maka tim pelaksana menggaris bawahi agenda penting pemecahan bersama masalah mitra yang bergerak di bidang kesehatan, manajemen, teknologi dan perancangan solusi yang ditawarkan atas berbagai permasalahan kelompok pedagang pasar. Maka tim pengusul bersama mitra mengusulkan sebuah program yang strategis dan konstruktif. Program ini memiliki tujuan untuk memperkuat pengetahuan kelompok mitra dalam rangka pencegahan penularan Covid-19. Pemberdayaan kelompok pedagang pasar Yadnya dengan memberikan bantuan sarana, keterampilan, pelatihan dan pendampingan. Justifikasi pengusul pengabdian bersama mitra untuk menyelesaikan persoalan prioritas.

\section{METODE PELAKSANAAN Sasaran, Tempat dan Waktu}

Sasaran dalam pengabdian ini berupa penyuluhan dan pelatihan dan pendampingan kepada para pedagang pasar yang berjumlah 40 orang, kepala pasar akan mensosialisasikan PKM kepada para pedagang.

\section{Pelaksanaan Kegiatan}

Pelaksanaan pengabdian ini diawali dengan identifikasi masalah yang terjadi di Pasar Yadnya, dilakukan koordinasi kepada Kepala pasar dan para pedagang. Sarana penyuluhan yang dipakai adalah presentasi dengan leaflet dan poster. Penyuluhan akan dilakukan oleh $\mathrm{dr}$ Putu Indah Budiapsari, M.si tentang Covid-19 meliputi pemaparan karateristik virus, cara penularan, cara penggunaan APD diberikan kepada para pedagang. Pelatihan Teknik cuci tangan yang baik dan benar akan dilakukan oleh dr Wayan Widhidewi, M.Biomed. Sebelum dan sesudah penyuluhan, pemateri memberikan beberapa pertanyaan (pretest dan post test) yang tujuannya untuk menilai tingkat pemahaman peserta terhadap materi yang diberikan.

Alokasi waktu penyampaian materi adalah 45 menit, diikuti dengan sesi tanya jawab yakni 
selama 15 menit. Pre-test dan post-test akan dilakukan dengan memberikan pertanyaan langsung kepada para pedagang menggunakan kuisioner.

\section{Keterkaitan dan Rancangan Evaluasi}

a. Bentuk Partisipasi Mitra

Dalam pelaksanaan kegiatan ini kami melakukan kerjasama dengan pihak Pasar yadnya dalam hal penentuan topik dan metode pelatihan, pemilihan sasaran, perijinan, peralatan, dan tempat pelaksanaan kegiatan.

b. Adapun indikator keberhasilan dalam promosi kesehatan ini adalah:

1. Evaluasi tahap persiapan dilakukan dengan menilai adanya kendala dalam hal menentukan topik, metode promosi kesehatan, pemilihan sasaran, mendapatkan ijin, persiapan materi, dan persiapan alat.

2. Evaluasi tahap pelaksanaan dinilai dari sikap peserta mau mendengarkan penyuluhan dan dapat berpartisipasi dalam tanya jawab mengenai materi yang diberikan, minimal 3 penanya.

3. Output :

- Peserta yang hadir dalam kegiatan ini minimal 34 orang $(85 \%$ dari total sasaran).

- Meningkatnya pengetahuan pedagang pasar mengenai COVID-19 yang dapat dilihat dari hasil post-test minimal peserta menjawab $85 \%$ jawaban dengan benar.
Seluruh peserta selanjutnya dibimbing secara penuh untuk menerapkan iptek melalui ceramah, praktek, demonstrasi, pelatihan, dan pendampingan. Kegiatan ini diharapkan menjadi ajang transfer ilmu, pengetahuan, keterampilan yang berefek pada peningkatan pengetahuan, pengalaman, kemampuan SDM peserta

\section{HASIL}

Sebelum dilakukan pemberian materi, dilakukan pretest untuk mengetahui gambaran pengetahuan, sikap, dan perilaku awal pedagang pasar terhadap infeksi Covid-19 dan cara pencegahannya. Form pertanyaan untuk pretest dan posttest berisi 16 pertanyaan.

- Gambaran Pengetahuan pedagang pasar terhadap Covid-19

Sebelum pelaksanaan kegiatan, kami melakukan eksplorasi atau survei dengan menggunakan kuisioner kepada pedagang pasar. Terdapat 20 peserta yang melakukan pengisian kuisioner, dengan hasil sebagai berikut, $100 \%$ peserta sudah mengetahui kepanjangan Covid-19, sebanyak $100 \%$ peserta sudah mengetahui bahwa Covid-19 disebabkan oleh virus. Cara penularan Covid-19 sudah dipahami oleh $97 \%$ peserta, namun terdapat $3 \%$ yang tidak mengetahui cara penularannya. Sebanyak $96 \%$ peserta sudah mengetahui cara mencegah Covid-19 namun 4\% tidak mengetahui cara penularan Covid19. 
Tabel 1. Hasil Menjawab pertanyaan pengetahuan peserta tentang Covid-19

\begin{tabular}{|l|l|l|l|l|l|}
\hline No & Pertanyaan & Pre Test & \multicolumn{3}{l|}{ Post Test } \\
\cline { 3 - 6 } & & Benar & Salah & Benar & Salah \\
\hline 1 & Apakah Kepanjangan Covid-19? & $90 \%$ & $10 \%$ & $100 \%$ & $0 \%$ \\
\hline 2 & Mikroba Jenis Apakah Covid-19? & $90 \%$ & $10 \%$ & $100 \%$ & $0 \%$ \\
\hline 3 & Bagaimanakah Cara Penularan Covid-19? & $97 \%$ & $3 \%$ & $100 \%$ & $0 \%$ \\
\hline 4 & Bagaimanakah Cara Mencegah Covid-19? & $96 \%$ & $4 \%$ & $100 \%$ & $0 \%$ \\
\hline
\end{tabular}

- Gambaran Perilaku pedagang pasar yadnya terhadap Covid-19.

Perilaku peserta dalam menghadapi Covid-19 juga dilakukan analisa, hasilnya adalah sebanyak $97 \%$ peserta menjawab benar etika batuk dan bersin yang benar, namun terdapat $3 \%$ yang salah menjawab. Pengertian social distancing dijawab benar oleh $93,6 \%$ dan $6,1 \%$ menjawab salah. Perilaku yang berisiko memindahkan virus dijawab benar oleh $87,9 \%$ peserta dan 12,1 $\%$ menjawab salah. Sebanyak $87,9 \%$ peserta sudah melakukan cara cuci tangan yang benar, namun $12,1 \%$ peserta belum melakukan cuci tangan yang benar. Seluruh peserta sudah benar dalam menjawab kapan saat yang tepat untuk mencuci tangan begitu pula perilaku saat pulang ke rumah selesai berjualan.

Tabel 2. Hasil Menjawab Pertanyaan Perilaku Peserta tentang pencegahan Covid-19

\begin{tabular}{|l|l|l|l|l|l|}
\hline No & Pertanyaan & \multicolumn{2}{l|}{ Pre Test } & \multicolumn{2}{l|}{ Post Test } \\
\cline { 4 - 6 } & & Benar & Salah & Benar & Salah \\
\hline 1 & $\begin{array}{l}\text { Bagaimanakah Etika Batuk Atau Bersin Yang } \\
\text { Benar? }\end{array}$ & $97 \%$ & $3 \%$ & $100 \%$ & $0 \%$ \\
\hline 2 & $\begin{array}{l}\text { Apakah Yang Dimaksud Dengan Social } \\
\text { Distancing? }\end{array}$ & $93.9 \%$ & $6.1 \%$ & $100 \%$ & $0 \%$ \\
\hline 3 & Perilaku Apa Yang Berisiko Memindahkan Virus & $87.9 \%$ & $12.1 \%$ & $100 \%$ & $0 \%$ \\
\hline 4 & Bagaimanakah Cara Cuci Tangan Yang benar & $87.8 \%$ & $12.1 \%$ & $100 \%$ & $0 \%$ \\
\hline 5 & Kapan Sebaiknya Anda Cuci Tangan? & $100 \%$ & $0 \%$ & $100 \%$ & $0 \%$ \\
\hline 6 & $\begin{array}{l}\text { Bagaimana Perilaku Yang Benar Setelah Selesai } \\
\text { Berjualan Saat Pulang Ke Rumah? }\end{array}$ & $100 \%$ & $0 \%$ & $100 \%$ & $0 \%$ \\
\hline
\end{tabular}

- Gambaran Sikap Pedagang Pasar terhadap Covid-19

Analisa terhadap sikap pedagang pasar juga dilakukan, hasilnya adalah seluruh peserta sudah mengethui anjuran pemerintah dalam mencegah penyebaran Covid-19, sebanyak $97 \%$ sudah mengetahui karantina wilayah yang dimaksudkan oleh pemerintah, namun terdapat $3 \%$ peserta yang belum mengetahuinya. Seluruh peserta sudah mengetahui apa yang dilakukan apabila ada petugas medis yang diusir oleh masyarakat. Sebanyak $97 \%$ peserta sudah mengetahui cara penanganan apabila ada keluarga yang mengalami panas, batuk dan sesak, namun 3\% tidak mengetahui alur penangannya. Semua peserta 
menjawab benar gaya hidup yang baik untuk melawan Covid-19, sebanyak 97\% peserta mengetahui cara menurunkan stress di masyarakat terhadap ketakutan akibat Covid-19, namun $3 \%$ peserta nampaknya tidak mengetahui cara menurunkan stress di masyarakat akibat Covid-19.

Tabel 3. Hasil Menjawab pertanyaan tentang Sikap Peserta dalam penanganan Covid-19

\begin{tabular}{|l|l|l|l|l|l|}
\hline No & Pertanyaan & \multicolumn{2}{l|}{ Pre Test } & \multicolumn{2}{l|}{ Post Test } \\
\cline { 4 - 6 } & & Benar & Salah & Benar & Salah \\
\hline 1 & $\begin{array}{l}\text { Bagaimanakah Anjuran Pemerintah Dalam } \\
\text { Mencegah Covid-19 }\end{array}$ & $100 \%$ & $0 \%$ & $100 \%$ & $0 \%$ \\
\hline 2 & Apakah Yang Dimaksud Karantina Wilayah? & $97 \%$ & $3 \%$ & $100 \%$ & $0 \%$ \\
\hline 3 & $\begin{array}{l}\text { Bagaimana Sikap Anda Bila Melihat Warga Yang } \\
\text { Mengusir Perawat Di Rumah Sakit? }\end{array}$ & $100 \%$ & $0 \%$ & $100 \%$ & $0 \%$ \\
\hline 4 & $\begin{array}{l}\text { Apakah Yang Akan Anda Lakukan Apabila Anda } \\
\text { Atau Keluarga Mengalami Batuk Sesak Dan Panas? }\end{array}$ & $97 \%$ & $3 \%$ & $100 \%$ & $0 \%$ \\
\hline 5 & $\begin{array}{l}\text { Bagaimanakah Gaya Hidup Yang Baik Untuk } \\
\text { Melawan Covid-19? }\end{array}$ & $100 \%$ & $0 \%$ & $100 \%$ & $0 \%$ \\
\hline 6 & $\begin{array}{l}\text { Bagaimana Cara Menurunkan Stress Atau Ketakutan } \\
\text { Masyarakat Pada Covid-19? }\end{array}$ & $97 \%$ & $3 \%$ & $100 \%$ & $0 \%$ \\
\hline
\end{tabular}

Melalui hasil pretest dan posttest di atas diketahui bahwa semua peserta mengalami peningkatan pengetahuan

\section{Pelaksanaan kegiatan}

Pemberian pelatihan dilakukan oleh narasumber dr. Putu Indah Budiapsari, M.Si dan dihadiri oleh 23 peserta. Metode pemberian materi dilakukan seperti metode ceramah, beberapa demonstrasi mengenai teknik cuci tangan yang baik dan benar serta cara penggunaan alat pelindung diri untuk bekerja di lapangan, dan dilanjutkan dengan diskusi atau tanya jawab.

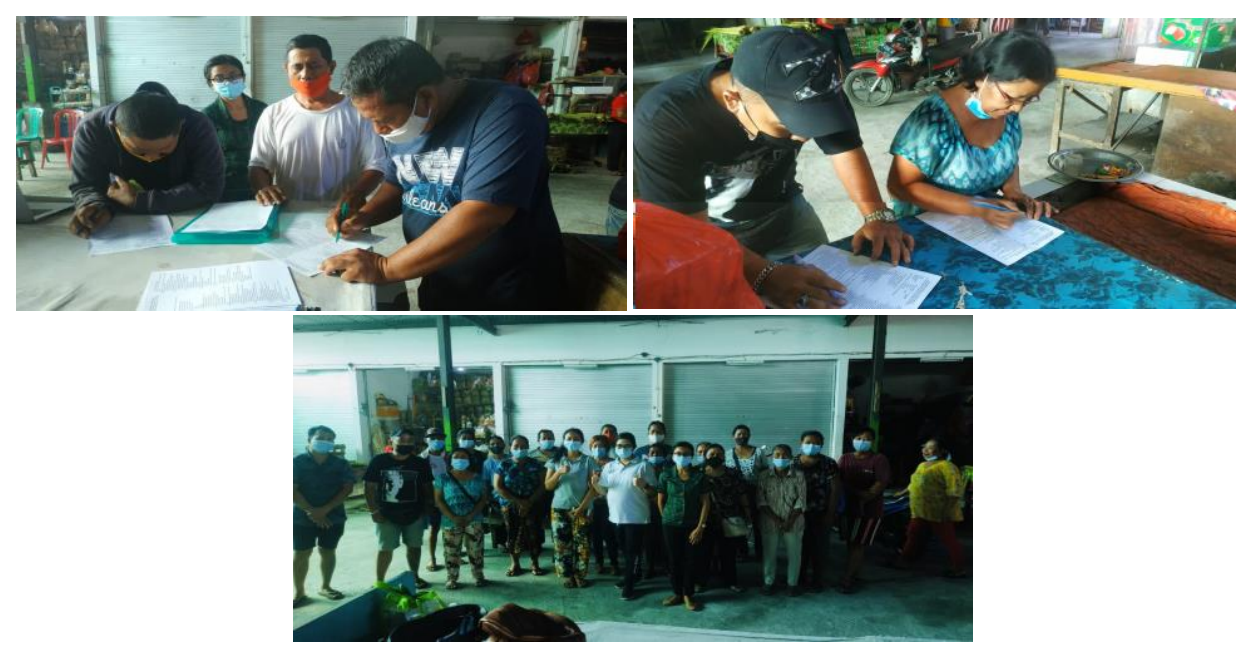

Gambar 2. Dokumentasi Kegiatan PKM Monitoring dan Evaluasi 
https://ejournal.warmadewa.ac.id/index.php/wicaksana

Kami melaksanakan pendampingan keluarga sebagai metode evaluasi dan monitoring terhadap keberlanjutan atau implementasi teknik cuci tangan dan pemakaian laat pelindung diri dalam pekerjaan sehari-hari. Masing-masing fasilitator mendatangi petani ke rumah tempat tinggalnya. Pedagang yang didatangi tersebut adalah peserta yang aktif bertanya saat kegiatan berlangsung, sebanyak 1 orang peserta yaitu Luh Made Artini. Para peserta diingatkan kembali tentang perilaku bersih dan hidup sehat, serta memakai alat pelindung diri untuk berjualan sehari-hari.

\section{KESIMPULAN}

Kesimpulan yang dapat diambil dari kegiatan pengabdian ini adalah pedagang pasar sudah tahu cara mencegah penyebaran infeksi Covid19. Terdapat peningkatan pengetahuan, sikap dan perilaku pencegahan penyebaran Covid-19 pedagang pasar setelah diberikan penyuluhan dan pelatihan tentang penggunaan APD serta cuci tangan yang baik dan benar. Perlu dibentuk tim yang keberlanjutan dalam menerapkan penggunaan APD dan cuci tangan dalam kehidupan sehari-hari. Perlu dibentuk tim yang akan melaporkan kepada petugas kesehatan apabila ada masyarakat yang dicurigai terinfeksi Covid-19 berdasarkan gejalagejalanya.

\section{DAFTAR PUSTAKA}

1. Sekretariat daerah kota Denpasar. Pengaturan Pembatasan Kegatan Masyarakat di Tingkat Desa, kalurahan, dan Desa adat dalam percepatan penanganan Corona virus disease 2019 (Covid-19). Bagian Hukum dan Hak Asasi manusia Pemerintah Kota Denpasar.

2. Direktorat Jenderal Pencegahan Dan Pengendalian Penyakit (P2p). 2020. Pedoman Kesiapsiagaan Menghadapi Coronavirus Disesase (Covid-19). Jakarta: Kementerian Kesehatan RI.

3. Safrizal ZA, Danang Insita Putra, Safriza Sofyan, Dr. Bimo. 2020. Pedoman Umum Menghadapi Pandemi Covid-19 Bagi Pemerintah daerah. Jakarta: Kementerian Dalam Negeri.

4. Menteri Kesehatan Republik Indonesia. 2020. Permenkes 9 tahun 2020 tentang Pedoman PSBB dalam rangka Percepatan Penanganan COVID-19. Jakarta: Kementerian Kesehatan RI.

5. Presiden Republik Indonesia. 2020. Peraturan Pemerintah No. 21 tahun 2020 tentang Pembatasan Sosial Berskala Besar dalam rangka Percepatan Penanganan COVID-19.

6. Dzakwan, MAH. Menuju Situasi Normal Baru: Kesiapan Bali dalam Menangani COVID-19. CSIS Commentaries DMRU084-ID 26 June 2020.

7. Sembiring, R, Suryani, DE. Sosialisasi Penerapan Protokol Kesehatan Di Masa Pandemi Dengan Pembagian Masker Kesehatan Kepada Para Pedagang Dan Pengunjung Pasar Tradisional Pajak Sore Padang Bulan. Jurnal Abdimas Mutiara Volume 1, Nomor: 2, September 2020. 